\section{Karyologic and Heterosis Studies of the Artificial Inter- and Intraspecific Hybrids of Viola Xwittrockiana and Viola cornuta}

\author{
Xiaohua Du${ }^{1}$ and Mengye Wang \\ Henan Institute of Science and Technology, Xinxiang, Henan Province, \\ 453003, China
}

\author{
Aneta Słomka \\ Department of Plant Cytology and Embryology, Jagiellonian University, 9 \\ Gronostajowa St., 30-387 Cracow, Poland
}

Huichao Liu

Henan Institute of Science and Technology, Xinxiang, Henan Province, 453003, China

Additional index words. pansies, inbred lines, aneuploid chromosome numbers, artificial crossing, flower size increase, $F_{1}$ progeny

\begin{abstract}
An artificial crossing was made between four Viola $\times$ wittrockiana $(2 n=48)$ lines and one Viola cornuta inbred $(2 n=26)$ line as well as among $V$. Xwittrockiana lines to investigate the cytologic characteristics, fertility, and heteroses of hybrids. The sizes of flowers and stomata and the leaf areas of the $V$. Xwittrockiana plants were larger than those of the $V$. cornuta plants. The karyologic stability of $V$. cornuta was greater than that of $V$. Xwittrockiana, and $\approx 20 \%$ of individuals in the latter deviated from the given $2 n=$ 48. Capsule setting after interspecies hand pollination ranged from $28 \%$ to $94 \%$, and $F_{1}$ seed germination ranged from $16 \%$ to $88 \%$, revealing no obvious pre- or postzygotic selection mechanisms. The chromosome numbers in $V$. Xwittrockiana $\times V$. cornuta $\mathrm{F}_{1}$ seedlings varied $(2 n=34-38)$, with about half the cells exhibiting the intermediate $(2 n=$ 36) value. These interspecific hybrids exhibited positive heterosis in flower size (range, $11 \%$ to $66 \%$ ) and negative heterosis in plant height (range, $-12 \%$ to $-57 \%$ ). Both of these traits are desirable in pansy breeding programs.
\end{abstract}

Breeding methods for ornamental plants range from traditional selection breeding programs to modern biotechnological and genetic engineering methods. Many ornamental plants, including geraniums, impatiens, begonias, and primulas, originated from interspecific and intergeneric crosses, which leads to a high degree of heterozygosity in the resulting hybrids, with polyploidy and aneuploidy often occurring. In seedpropagated ornamentals with a considerable seed market, cultivars will normally be bred as hybrids based on inbred parental lines. The main emphasis in ornamental plant breeding is to improve the variety traits, novel color, form, size, number of flowers, flower vase life, repeat blooming, disease resistance, nutrient uptake capacity, and growth habits (De, 2017). Commercially available pansies

Received for publication 2 Apr. 2018. Accepted for publication 20 July 2018.

This research was supported by the Henan Province Science and Technology Research Project (no. 152102110088) and the Henan Institute of Science and Technology Provincial and Ministerial Achievement Award Cultivation Project (2017CG02).

${ }^{1}$ Corresponding author. E-mail: duxiaohua0124@, sina.com. are $F_{1}$ hybrids produced by hand crossing. Currently, such production of Viola tricolor maxima with hermaphrodite flowers requiring emasculation occasionally occurs at the expense of limited profitability (De, 2017; Reimann-Philipp, 1983).

Heterosis is a phenomenon whereby the phenotype of $F_{1}$ hybrids is superior to that of their parents. Intralocus interactions between alleles, complementation of dominant alleles, or interloci epistatic interactions are genetic mechanisms that may cause nonadditive phenotypic inheritance in hybrids. However, different views exist on what portion of the heterotic variation is modulated by each of these mechanisms (Fridman, 2015).

Viola $\times$ wittrockiana Gams ex Kappert., known as garden pansy, is one of the most common bedding plants worldwide, exhibiting rich flower colors, cold tolerance, and other charming characteristics, such as odor and taste (Fernandes et al., 2017; Lagibo et al., 2005; Li et al., 2014, and literature cited therein). This species is also studied as a promising source of natural antioxidants (Vukics et al., 2008). Present-day garden pansies are horticultural hybrids rather than a natural species. Initially, the species was selected as an interspecific hybrid resulting from the crossing of Viola L. sect. Melanium Ging. species (pansies), V. tricolor L., $V$. lutea Hudson, and V. altaica Ker-Gawler (Kroon, 1972). The species differs from wild pansies based on the absence of dark lines on the flower petals (nectar guides for pollinators) and the presence of huge blocks of color on the lower (anterior) and lateral petals called a "face." This pansy and its progeny have become popular with gardeners and breeders throughout Europe. At the turn of the 20th century, Charles Stewart bred clear color pansies without faces that were welcomed by North American gardeners. Currently, $V$. Xwittrockiana is one of the dominant hybrids among ornamental bedding plants in the U.S. market (Janick, 1998).

During the past 60 years, much of the innovative pansy breeding has been performed in Germany, the United States, and Japan (Zhang et al., 2010). New pansy varieties with different colors, such as shades of pink, rose, or orange, and unusual bicolor designs have been introduced and are available to gardeners. Studies using a simple selection method to reduce the ploidy level by crossing with diploids to improve uniformity, as well as an increase of polyploidy by mutagenesis to maximize plant morphologic and physiologic characters, have already been performed (Dalbato et al., 2013; Kroon, 1972; Lagibo et al., 2005). Lagibo et al. (2005) demonstrated the positive influence of increased polyploid level on frost tolerance and winter survival of garden pansy.

Along with the increasing popularity of pansy cultivation worldwide, breeding goals continue to develop. Recently, V. cornuta L. (horned pansy) has been crossed successfully with $V$. Xwittrockiana for the creation of new desirable phenotypic traits, such as increased flowering, plant compactness, and tolerance to environmental stresses ( $\mathrm{Li}, 2010$; Liu, 2008; Zhang and Gu, 2009). Currently, some hybrid cultivars of these two species-e.g., 'Nature Series' and 'Power Mini' - are bred by the Japanese seed company Takii Seed (Kyoto, Japan) and Sakata Seed (Japan) respectively. To meet the ever-growing expectations of customers (practical approach) and to increase the predictability of the crossing treatments (basic science approach), we adopted four inbred lines of $V$. ×wittrockiana and one inbred line of $V$. cornuta to investigate the cytologic basis of hybridization and heterosis in their hybrids.

\section{Materials and Methods}

Derivation of inbred lines of $V . \times$ wittrockiana and $V$. cornuta and their morpho-anatomic description. The breeding experiments were performed in the garden field of the Henan Institute of Science and Technology (Xinxiang, China) from 2015 to 2017. Four $V$. $\times$ wittrockiana inbred lines and one $V$. cornuta inbred line (Table 1; Fig. 1A-E) were generated from commercially available seeds by self-crossing for five or six generations, given accession numbers, and used as parental lines. Plants were grown in a closed plastic 
Table 1. The pedigrees, accession numbers. and origins of Viola cornuta and Viola $\times$ wittrockiana lines used for inter- and intraspecific crosses.

\begin{tabular}{|c|c|c|c|c|}
\hline No. & Name & Pedigree & Species & Origin \\
\hline$\overline{1}$ & JB-1-1-2 & $\begin{array}{l}\text { Inbred line derived } \\
\text { from Penny Blue }\end{array}$ & V. cornuta & Goldsmith seed \\
\hline 2 & DFM-11-2-1 & $\begin{array}{l}\text { Inbred line derived from } \\
\text { Frühblühende Mischung }\end{array}$ & $V . \times$ wittrockiana & $\begin{array}{l}\text { Gartenland GmbH } \\
\text { Aschersleben }\end{array}$ \\
\hline 3 & DFM-11-1-3 & $\begin{array}{l}\text { Inbred line derived from } \\
\text { Frühblühende Mischung }\end{array}$ & V. $\times$ wittrockiana & $\begin{array}{l}\text { Gartenland GmbH } \\
\text { Aschersleben }\end{array}$ \\
\hline 4 & DFM-8-4-3 & $\begin{array}{l}\text { Inbred line derived from } \\
\text { Frühblühende Mischung }\end{array}$ & V. $\times$ wittrockiana & $\begin{array}{l}\text { Gartenland GmbH } \\
\text { Aschersleben }\end{array}$ \\
\hline 5 & XXL-YB-1-1-1-1 & $\begin{array}{l}\text { Inbred line derived from } \\
\text { extra flower size }\end{array}$ & $V . \times$ wittrockiana & PanAmerican seed \\
\hline
\end{tabular}
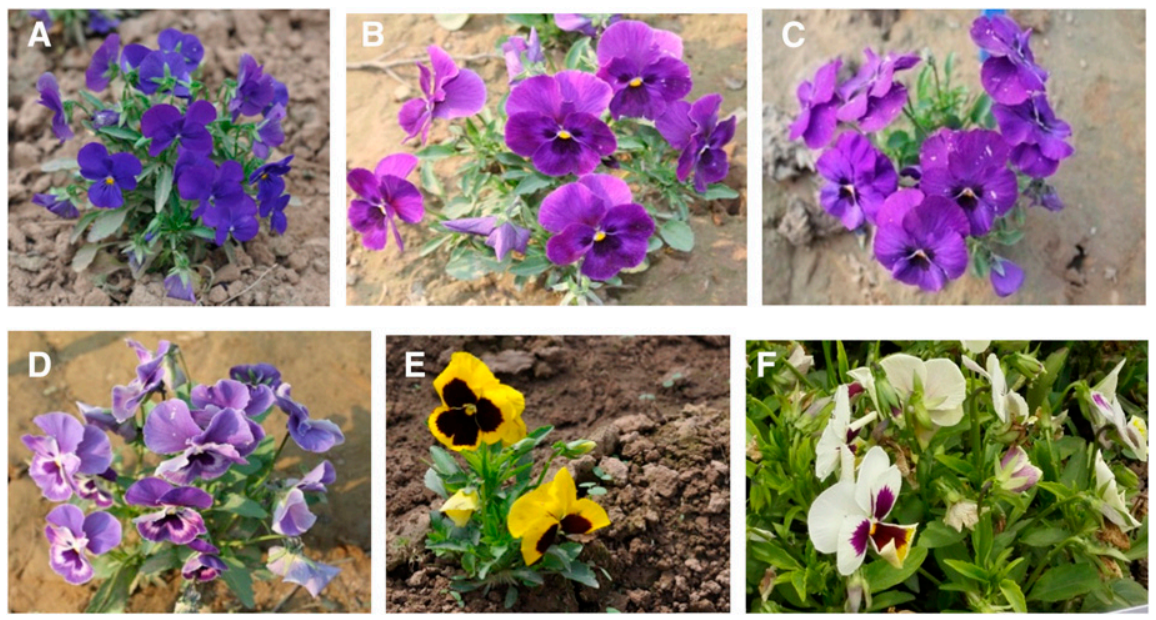

Fig. 1. (A) Plants of inbred lines of Viola cornuta during flowering. (B-E) Plants of inbred lines of Viola xwittrockiana during flowering. (F) Plants of hybrid of $V$. cornuta and $V$. xwittrockiana during flowering. (A) JB-1-1-2, (B) DFM-11-2-1, (C) DFM-11-1-3, (D) DFM-8-4-3, (E) XXL-YB-1-1-1-1, and (F) XXL-YB-1-1-1-1 $\times$ DFM-8-4-3.

chamber from Oct. 2015 to Mar. 2016 and then under insect netting from Apr. to June 2016 to avoid high temperatures and insect pollinators. Five plants of each line were selected for detailed morpho-anatomic analyses. The leaf stomata size (length and width) and density of each plant were measured and observed under a Nikon Eclipse 50i microscope (Nikon Corporation, Shanghai, China). The length and width of a completely developed leaf and the height (flower size) and width of a randomly selected flower were measured. Then, leaf and flower shape values were calculated (length-width and heightwidth ratios, separately). The leaf area was measured using the transparent square grid method (Qiao et al., 2004).

Artificial crossing of inbred lines of $V$. cornuta and $V$. ×wittrockiana to obtain $F_{1}$ progeny. Our artificial crossing design among five inbred lines adopted Griffing's method III of a complete diallelic cross (Griffing, 1956). Flower buds to be opened the next day were chosen and isolated with sulfuric acid paper bags. The buds used as maternal flowers were emasculated by the removal of all stamens. On the first day of flowering, pollen grains collected from male donor plants with freshly opened anthers were transferred by hand pollination to the stigmas of female donor plants. The pollinated flowers were then isolated with sulfuric acid paper bags and labeled immediately. One week later, the isolation bags were removed from the enlarged ovaries, and plants were housed under insect nets to avoid any repeated pollinations, which are possible in pansies as a result of stigma receptivity longer than 1 week (Miyajima, 2006). One month after crossing, mature capsules were collected, and the capsule settings were counted with respect to undeveloped ovaries. Five to six flowers per plant were emasculated and pollinated. A total of 24 plants were pollinated in $V$. cornuta $\times V$. $\times$ wittrockiana and 36 plants in $V$. $\times$ wittrockiana $\times V$. $\times$ wittrockiana.

$F_{1}$ germination and morphologic characteristics (heteroses). In Oct. 2016, selected, mature, well-developed seeds of the crosses and of parental plants were sowed in individual pots of planting trays filled with a peat-tovermiculite ratio $(\mathrm{v} / \mathrm{v})$ of $2: 1$ and were maintained in plastic chambers. Seeds were watered regularly. Two weeks after sowing, the number of germinated hybrid seeds was counted. Only those seedlings that were germinated 2 weeks after cultivation were taken into further consideration. The seedlings of inbred lines of $V$. $\times$ wittrockiana and $V$. cornuta and crossings were transplanted into $10-\mathrm{cm}$ (diameter) $\times$ 10 -cm (high) pots when they exhibited two to three true leaves. Plants were transplanted into the field in Mar. 2017, and were maintained for further growth and blossoming (Fig. 1F). Ten randomly selected plants of each accession were chosen in Apr. 2017 to investigate plant height, plant spread (width), flower number and size (height), flower shape (height-width ratio), leaf shape (length-width ratio), and area. A fully developed leaf and an open flower were measured per plant. Mid-parent heterosis of these characters was calculated according to the Eq. $100 \times\left[\mathrm{F}_{1}-\left(\mathrm{P}_{1}+\mathrm{P}_{2}\right) / 2\right] /$ $\left(\mathrm{P}_{1}+\mathrm{P}_{2}\right) / 2$ (Marame et al., 2009).

Chromosome counting in inbred lines and their $F_{1}$ hybrid progeny. The seeds of inbred lines and their $F_{1}$ progeny were germinated on filter paper soaked with distilled water at room temperature. Roots 1 to $2 \mathrm{~cm}$ in length were sampled, and their root tips were dissected under a stereomicroscope. The seedlings were pretreated for $24 \mathrm{~h}$ at $0{ }^{\circ} \mathrm{C}$ and fixed in a mixture of glacial acetic acid and absolute ethanol (3:1 ratio, $\mathrm{v} / \mathrm{v})$ for $24 \mathrm{~h}$. The fixed root tips were then macerated with $1 \mathrm{~mol} \cdot \mathrm{L}^{-1}$ hydrochloric acid at $60{ }^{\circ} \mathrm{C}$ for 6 to $8 \mathrm{~min}$. Finally, the material was stained with carbol fuchsin, flattened with a cover slip, and observed under a Nikon Eclipse 80i microscope (Nikon Corporation) with a magnification of 10 (eye lens) $\times 100$ (field lens). The images were generated using CellSens (ver. 1.12) Imaging Software (Olympus Corporation, Tokyo, Japan). At least 30 plates from 10 plants per accession were observed.

\section{Results}

Morpho-anatomic and cytologic characteristics of the inbred lines of $V$. cornuta and $V$. ×wittrockiana. Stomata length, stomata width, leaf area, and flower size of the $V$. cornuta inbred line $(118.1 \mu \mathrm{m}, 70.0 \mu \mathrm{m}, 2.5$ $\mathrm{cm}^{2}$, and $2.1 \mathrm{~cm}$, respectively) were reduced significantly compared with those of the $V$. $\times$ wittrockiana inbred lines (range, 140.4 $174.1 \mu \mathrm{m}, 85.4-116.2 \mu \mathrm{m}, 4.4-8.4 \mathrm{~cm}^{2}$, and $3.5-5.8 \mathrm{~cm}$, respectively) (Table 2 ). The $V$. cornuta inbred line exhibited increased stomatal density compared with $V$. × wittrockiana inbred lines, but the leaf and flower shapes did not differ significantly between the $V$. cornuta inbred line and the $V$. Xwittrockiana inbred lines (Table 2 ). The $V$. cornuta line (JB-1-1-2) was consistently $2 n=26$ in all investigated plants (Fig. 2A). More than $80 \%$ of plants in each inbred line of $V$. $\times$ wittrockiana were $2 n=48$ (Fig. 2B-E). The remaining plants were $2 n=44-46$ (Fig. $2 \mathrm{~F}-\mathrm{H}$ ). No intraindividual variability in chromosome number in inbred lines of either species was observed.

Capsule setting after inter- and intraspecific artificial pollination and seed germination of $F_{1}$ hybrids. Some obstacles, both prezygotic and postzygotic, are typically encountered in interspecific crossing, such as pollen-stigma incompatibility and hybrid embryo abortion. Even if these obstacles are overcome, $F_{1}$ interspecific hybrids can exhibit reduced fertility, which can measured as reduced seed setting and germination. The percentage of capsule setting after interspecific crossing ranged from $28 \%$ to $94 \%$ and from $18 \%$ to 
Table 2. Chromosome numbers, leaf microstructural characteristics, and flower parameters of Viola $\times$ wittrockiana and Viola cornuta inbred lines.

\begin{tabular}{|c|c|c|c|c|c|c|c|c|c|}
\hline No. & Name & $\begin{array}{c}\text { Chromosome } \\
\text { no. }\end{array}$ & Stomata length $(\mu \mathrm{m})^{\mathrm{z}}$ & $\begin{array}{l}\text { Stomata width } \\
\qquad(\mu \mathrm{m})^{\mathrm{z}}\end{array}$ & $\begin{array}{c}\text { Stomata } \\
\text { density }\left(\mathrm{mm}^{2}\right)^{z}\end{array}$ & 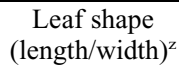 & $\begin{array}{l}\text { Leaf area } \\
\left(\mathrm{cm}^{2}\right)^{z}\end{array}$ & $\begin{array}{l}\text { Flower } \\
\text { ht }(\mathrm{cm})^{z}\end{array}$ & $\begin{array}{l}\text { Flower shape } \\
\text { (ht/width) }^{\mathrm{z}}\end{array}$ \\
\hline 1 & JB-1-1-2 & $2 n=2 x=26$ & $118.1(116.4,123.9)$ & $70.0(64.175 .7)$ & $24(23,25)$ & $2.3(2.0,2.9)$ & $2.5(2.3,2.6)$ & $2.1(2.0,2.5)$ & $0.9(0.8,0.9)$ \\
\hline 2 & DFM-11-2-1 & $2 n=8 x=48$ & $147.6(140.0,152.1)$ & $102.1(98.8,102.6)$ & 20) & $1.3(1.2,1.3)$ & $4.4(4$ & $3.5(3.3,3.6)$ & $0.8,0.9)$ \\
\hline 3 & DFM-11-1-3 & $2 n=8 x=48$ & $155.0(154.0,160.1)$ & $116.2(104.3,116.5)$ & & $1.4(1.4,1.5)$ & $4.9(4$ & $3.9(3.5,4.1)$ & $0.7,1.0)$ \\
\hline 4 & DFM-8-4-3 & $2 n=8 x=48$ & $174.1(163.3,181.4)$ & $85.4(79.2,98.4)$ & $13(12,21)$ & $2.1(2.0,2.3)$ & $6.9(6.5,7.0)$ & $4(3.8,4.1)$ & $0.9(0.9,1.0)$ \\
\hline 5 & XXL-YB-1-1-1-1 & $2 n=8 x=48$ & $140.4(139.0,145.8)$ & $91.3(83.2,106.4)$ & $15(12,20)$ & $2.6(2.0,2.8)$ & $8.4(8.3,8.8)$ & $5.8(5.2,6.0)$ & $1.0(0.9,1.0)$ \\
\hline
\end{tabular}

${ }^{\mathrm{z}} x(y, z)$, where $x$ is the median value recorded for the trait, $y$ is the smallest value, and $z$ is the largest value.
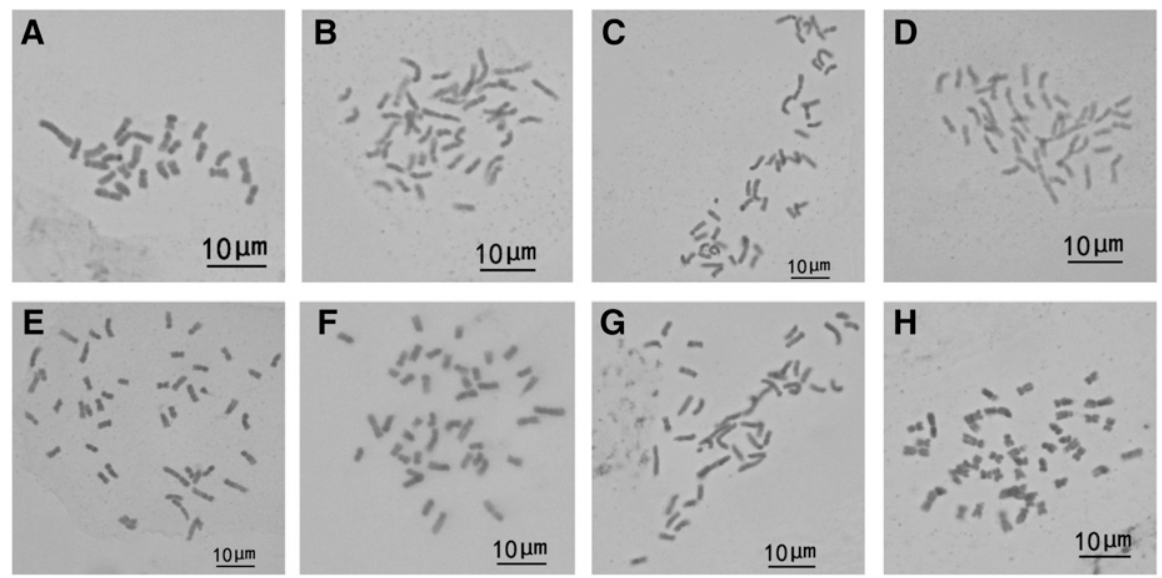

Fig. 2. (A-F, H) The euploid metaphase plates of Viola $\times$ wittrockiana and Viola cornuta inbred lines. $(\mathbf{G})$ The aneuploid metaphase plates of $V$. $\times$ wittrockiana and $V$. cornuta inbred lines. Original magnification was $10 \times 100$, and the image was generated using CellSens (ver. 1.12) Imaging Software (Olympus Corporation, Tokyo, Japan). (A) JB-1-1-2 $(2 n=26)$, (B) DFM-11-2-1 $(2 n=48)$, (C) DFM-11-1-3 $(2 n=48),($ D) DFM-8-4-3 $(2 n=48),($ E) XXL-YB-1-1-1-1 $(2 n=48),($ F $)$ XXL-YB-1-1-1-1 $(2 n=44)$, (G) DFM-11-1-3 $(2 n=45)$, and (H) DFM-11-2-1 $(2 n=46)$.

$90 \%$ after intraspecific crossing (Table 3 ). The percentages of seed germination ranged from $16 \%$ to $88 \%$ for the $\mathrm{F}_{1}$ hybrids of $V$. $\times$ wittrockiana $\times V$. cornuta and from $9 \%$ to $98 \%$ for $V$. $\times$ wittrockiana $\times V$. $\times$ wittrockiana. The differences in the percentages of capsule setting and seed germination were reflected mainly in crossing direction rather than between interspecies or intraspecies (Table 3).

Variation in chromosome numbers of intra- and interspecific $F_{1}$ hybrids. High diversity in chromosome number was noted among inter- and intraspecific artificial hybrids. The chromosome number in $\mathrm{F}_{1}$ hybrids between $V$. cornuta and $V$. × wittrockiana was $2 n=34-38$, whereas that in the hybrids between inbred lines of $V$. ×wittrockiana was $2 n=39-48$ (Fig. 3). Both intra- and interindividual variability in chromosome number were observed. However, the most frequent chromosome numbers were close to the middle value of the chromosome number ranges. The most frequent value was $2 n=36$ (49.4\% of cells) for interspecific crossing and $2 n=46(43.3 \%$ of cells) for intraspecific crossing. The percentage of cells with extreme values was relatively low (Figs. 3 and 4).

Heterosis of inter- and intraspecific $F_{1}$ hybrids. Hybrids typically exhibit heterosis in plant vigor and tolerance to environmental conditions. The inter- and intraspecific $\mathrm{F}_{1}$ hybrids in this study exhibited various heteroses with respect to different characters. We chose to analyze those characters that were the most discriminative for the two species (leaf area and flower size) and those characters most desired by breeders (e.g., flower number, plant height). With regard to flower size, all the $F_{1}$ hybrids yielded positive heterosis, with interspecific hybrids varying from $11 \%$ to $66 \%$ (flower size range, 3.3-6.4 $\mathrm{cm}$ ) and intraspecific hybrids varying from $23 \%$ to $75 \%$ (flower size range, $4.3-7.6 \mathrm{~cm}$ ). The hybrids became shorter, yielding negative heterosis in interspecific hybrids (from $-12 \%$ to $-57 \%$ ) and in intraspecific hybrids (from $-15 \%$ to $-42 \%$ ) compared with parental lines. The leaf area and plant width of the hybrids displayed significant positive or negative heterosis depending on crossed lines and the direction of crossing. With regard to flower number, interspecific hybrids exhibited positive heterosis when $V$. cornuta served as the male parent but negative heterosis when $V$. cornuta served as the female parent. Most intraspecific hybrids exhibited negative heterosis in flower number (Table 3 ).

\section{Discussion}

Based on cytologic and molecular analyses, most pansies from the section Melanium originate from hybridization events leading to explosive, rapid reticulate radiation (Ko et al., 1998; Yockteng et al., 2003). High genetic similarity and the lack of interspecific barriers ensure the generation of fertile hybrids with only slightly reduced pollen viability, even between species at different ploidy levels (Słomka et al., 2018). In addition, our results support this claim given that the frequency of capsule setting after interspecies crossing and seed germination of $F_{1}$ hybrids was generally high. The revealed differences resulted mostly from crossing combination and direction.

The current large-flowered garden pansy ( $V$. $\times$ wittrockiana) originated from a cross between $V$. tricolor $(n=13), V$. lutea $(n=24)$, and $V$. altaica $(n=11)$ (Kroon, 1972). The chromosome number of the majority of pansy varieties is $2 n=48$ according to Horn (1956), whereas Kroon (1972) reported $2 n=52$ in the group Hollandse Reuzen (Hemelsblauw, Goudgeel, Wit). All of the inbred lines of $V$. $\times$ wittrockiana in our study were $2 n=48$. In general, garden pansies with 48 chromosomes are commonly recognized as octaploid, with $x=6$ as the base chromosome number (Ajalin et al., 2002), whereas $V$. cornuta have $x=13$. This value is different from earlier counts demonstrating $x=11$ (Marcussen et al., 2010, and literature cited therein), which could be recognized as diploid. However, this chromosome number seems to be secondary. Clausen (1927) argued that the genome of 13 chromosomes is not primary for $V$. tricolor. Early cytotaxonomic articles postulated $x=11$ or $x=5$ (Clausen, 1931), whereas the most recent phylogenetic studies indicate $x=7$ (Yockteng et al., 2003) and $x=12$ (Marcussen et al., 2015) as the base chromosome number for the Melanium section.

A crossing between $V$. ×wittrockiana and $V$. cornuta should, theoretically, yield plants with $2 n=37$. In fact, the majority of cells were $2 n=36$; however, this number deviated in both directions and ranged from 34 to 38 . The variability of hybrid derivatives within such a broad range of chromosome numbers, including those with odd numbers, is not rare in pansies and was described in several species (Krahulcová et al., 1996. and literature cited therein). In our experiment, only $\mathrm{F}_{1}$ progeny were analyzed, and these progenies typically exhibit increased chromosome variability compared with the following generations of hybrids. However, the relatively high karyologic stability of $F_{1}$ is a good prognosis for future breeding treatments of these plants. The variability in chromosome number in interspecific hybrids may result from the karyologic variability of $V$. $\times$ wittrockiana $(\approx 20 \%$ of plants with chromosome numbers other than $2 n=48$ ) and/or from incomplete genomic stability of one or two parental species. As an indicator of regular meiosis and genome stability, pollen viability results indicate that the garden pansy exhibits a less stable genome compared with 


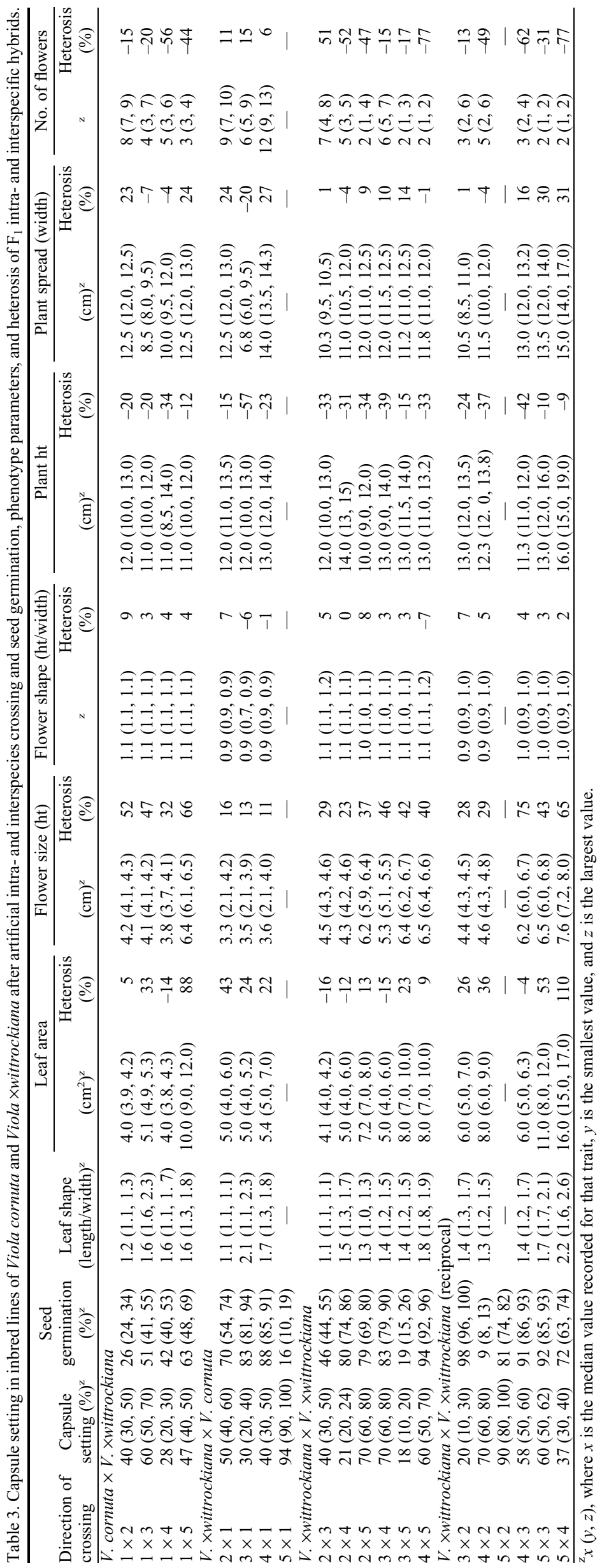

the horned pansy. The pollen viability of $V$. $\times$ wittrockiana is typically reduced compared with $V$. cornuta (Szczudło, 2004; personal observation). Furthermore, in crosses of $V$. ×wittrockiana inbred lines, descending aneuploidy $(2 n=39-48)$ was clearly visible.

Polyploids typically exhibit exuberant characteristics, such as thick, broad leaves with large stomata and magnificent flowers. The same finding applies to hybrids (including allopolyploids) (Chen, 2010). Ajalin et al. (2002) found that the stomata size of hexadecaploid plants was increased compared with octaploid plants of $V$. $\times$ wittrockiana, but leaf indices of hexadecaploids were reduced compared with octaploid plants. In this study, we observed that the leaf area and stomata and flower size of the $V$. ×wittrockiana inbred lines were increased significantly compared with the $V$. cornuta inbred line, but we observed no distinct differences in leaf shape corresponding to the leaf index between the $V$. ×wittrockiana inbred and the $V$. cornuta lines. In $V$. ×wittrockiana, additive genetic variance in the transmission of parental petal characteristics (superior and lateral petal ratio and area) to the progeny is extremely important and should be taken into account by breeders (Yoshioka et al., 2006).

The hybrids between $V$. cornuta and $V$. $\times$ wittrockiana and between $V$. $\times$ wittrockiana lines exhibited positive heterosis in flower size. These findings are consistent with the results of $\mathrm{Li}$ (2010). However, negative heterosis in plant height was noted, which is in contrast to the results of $\mathrm{Li}$ (2010) and likely a result of the different genetic backgrounds of the plant material we used. Thus, the flowers of $\mathrm{F}_{1}$ hybrids between $V$. cornuta and $V$. $\times$ wittrockiana used in this experiment have a tendency to become larger, and the plants tend to become more compact. These features of the hybrid are ideal for using large-flower pansies as bedding plants. Given that the experiment was not replicated across several environments, the phenotypic results we recorded may not be representative. However, the results are consistent with the description of the natural hybrid $V$. cornuta $\times V$. $\times$ wittrockiana $(V$. $\times$ williamsii Wittr.), which differs from $V$. cornuta based on wider, slightly overlapping petals, with lateral petals directed outward or upward (Marcussen et al., 2010). The positive heterosis with respect to plant height and flower size was also described in other $F_{1}$ ornamental hybrids, such as hybrids of inbred lines of Helianthus annuus, Petunia hybrida, Dendranthema morifolium $\times D$. nankingense (Bayat et al., 2012; Cheng et al., 2010; Goksoy et al., 2000).

To conclude, intra- $(V$. $\times$ wittrockiana $)$ and interspecific ( $V$. cornuta and $V$. $\times$ wittrockiana) plants exhibited relatively high stability in chromosome numbers of $\mathrm{F}_{1}$ individuals, which serves as a good prognosis for future breeding treatments of these plants. Positive heterosis in flower size and negative heterosis in plant height was noted in both breeding treatments. However, these findings require 


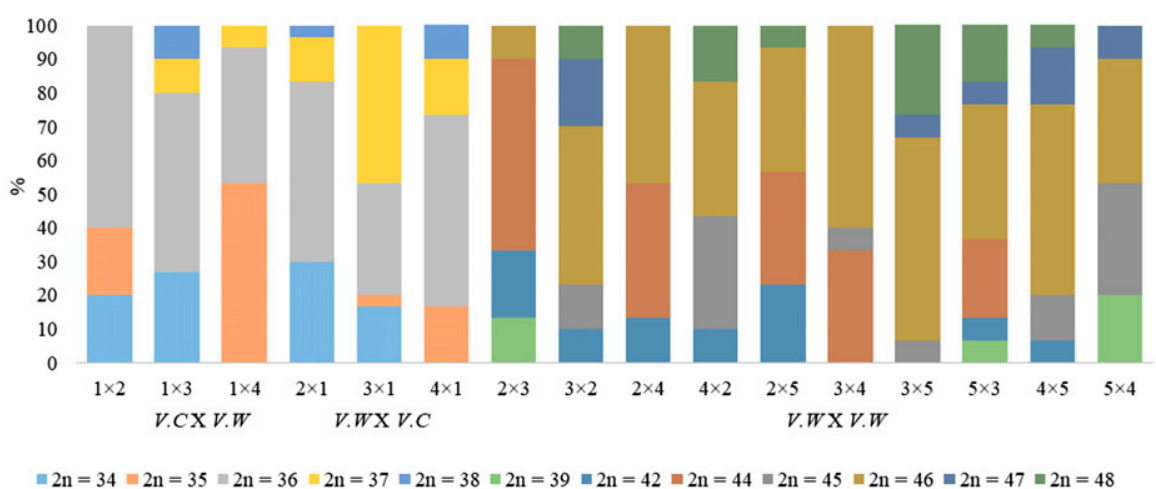

Fig. 3. The distribution of chromosome numbers in cells of interspecific hybrids between Viola $\times$ wittrockiana and Viola cornuta $(V . C \times V . W, V . W \times V . C)$ and intraspecific hybrids between $V$. $\times$ wittrockiana lines $(V . W \times V . W)$.
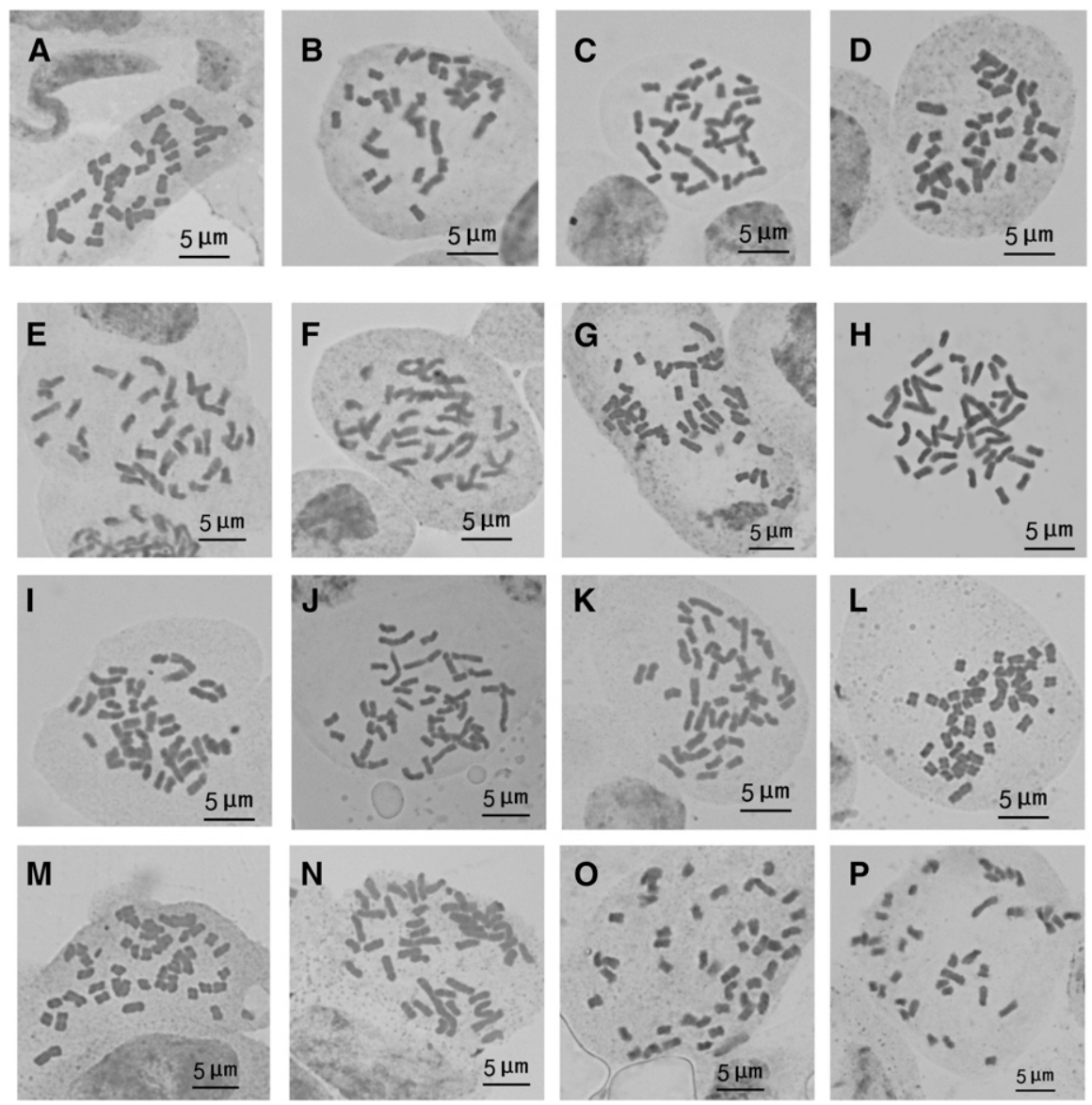

Fig. 4. (A-F) The selected metaphase plates of hybrids between Viola $\times$ wittrockiana and Viola cornuta inbred lines. (G-P) The selected metaphase plates of hybrids between $V$. Xwittrockiana inbred lines. Original magnification was $10 \times 100$, and the image was generated using CellSens (ver. 1.12) Imaging Software (Olympus Corporation, Tokyo, Japan). (A) $1 \times 2(2 n=36),(\mathbf{B}) 2 \times 1(2 n=36),(\mathbf{C}) 1 \times 3$ $(2 n=34)$, (D) $3 \times 1(2 n=36)$, (E) $1 \times 4(2 n=35)$, (F) $1 \times 5(2 n=36),(\mathbf{G}) 2 \times 3(2 n=44),(\mathbf{H}) 3 \times 2(2 n=46)$, (I) $2 \times 4(2 n=44),($ J) $4 \times 2(2 n=46),(\mathbf{K}) 2 \times 5(2 n=46),(\mathbf{L}) 3 \times 4(2 n=46),(\mathbf{M}) 3 \times 5(2 n=46),(\mathbf{N}) 5 \times 3$ $(2 n=45),(\mathbf{O}) 4 \times 5(2 n=46)$, and (P) $5 \times 4(2 n=39)$.

further study, including block design and season/space replications, to eliminate environmental effects and to open up new possibilities for pansy breeding programs. Although seeds of $V$. $\times$ williamsii (described as a hybrid between $V$. cornuta and $V$. $\times$ wittrockiana) are commercially available, basic and applied knowledge of this ornamental plant was not known before this study.

\section{Literature Cited}

Ajalin, I., F. Kobza, and J. Doležel. 2002. Ploidy identification of doubled chromosome number plants in Viola $\times$ wittrockiana Gams. M 1-generation. Hort. Sci. (Prague) 29(1):35-40.

Bayat, H., H. Neamati, A. Bagheri, A. Tehranifar, and M. Saie. 2012. Estimation of heterosis and combining ability in petunia (Petunia hybrida Hort.). Not. Sci. Biol. 4(3):151-157.
Chen, Z.J. 2010. Molecular mechanisms of polyploidy and hybrid vigor. Trends Plant Sci. 15(2):57-71.

Cheng, X., S. Chen, F. Chen, W. Fang, Y. Deng, and L. She. 2010. Interspecific hybrids between Dendranthema morifolium (Ramat.) Kitamura and D. nankingense (Nakai) Tzvel. achieved using ovary rescue and their cold tolerance characteristics. Euphytica 172(1):101-108.

Clausen, J. 1927. Chromosome number and the relationship of species on the genus Viola. Ann. Bot. 41(164):677-714.

Clausen, J. 1931. Cytogenetic and taxonomic investigations in Melanium violets. Hereditas 15(3): 219-308.

Dalbato, A.L., F. Kobza, and L.M. Karlsson. 2013. Effect of polyploidy and pollination methods on capsule and seed set of pansies (Viola $\times$ wittrockiana Gams). Hort. Sci. (Prague) 40(1):22-30.

De, L.C. 2017. Improvement of ornamental plants: A review. Intl. J. Hort. 7:180-204.

Fernandes, L., S. Casbal, J.A. Pereira, J.A. Saraiva, and E. Ramalhosa. 2017. Edible flowers: A review of the nutritional, antioxidant, antimicrobial properties and effects on human health. J. Food Compos. Anal. 60:38-50.

Fridman, E. 2015. Consequences of hybridization and heterozygosity on plant vigor and phenotypic stability. Plant Sci. 232:35-40.

Goksoy, A.T., A. Turkec, and Z.M. Turan. 2000. Heterosis and combining ability in sunflower (Helianthus annuus). Indian J. Agr. Sci. 70(8): 525-529.

Griffing, B. 1956. Concept of general and specific combining ability in relation to diallel crossing systems. Austral. J. Biol. Sci. 9(4):463-493.

Horn, W. 1956. Untersuchungenüber die cytologischen and genetischen Verhältnisse beim Gartenstiefmutterchen Viola tricolor maxima hort. ( $=V$. wittrockiana Gams.), einer polyploiden Bastardart. Der Züchter 26(7-8):193-207.

Janick, J. 1998. Hybrids in horticultural crops, p. 45-56. In: K.R. Lamkey and J.E. Staub (eds.). Concepts and breeding of heterosis in crop plants. CSSA Spec. Publ. 25. CSSA, Madison, WI.

Ko, M.K., J. Yang, Y.H. Jin, C.H. Lee, and B.J. Oh. 1998. Genetic relationships of Viola species evaluated by random amplified polymorphic DNA analysis. J. Hort. Sci. Biotechnol. 73(5): 601-605.

Krahulcová, A., F. Krahulec, and J. Kirschner. 1996. Introgressive hybridization between a native and an introduced species: Viola lutea subsp. sudetica versus $V$. tricolor. Folia Geobot. 31(2):219-244.

Kroon, G.H. 1972. Reduction of ploidy level of tetraploid large-flowered garden pansies (Viola $\times$ wittrockiana Gams.) to diploid level after crossing with diploid $V$. tricolor L. Euphytica 21(2): $165-170$

Lagibo, A.D., F. Kobza, and P. Suchánková. 2005. Polyploidy effects on frost tolerance and winter survival of garden pansy genotypes. Hort. Sci. (Prague) 32(4):138-146.

Li, Q. 2010. Preliminary study on cross breeding between Viola ( $V$. cornuta) and Pansy (Viola $\times$ wittrockiana). Huazhong Agricultural Univ., Wuhan, China. MS thesis. (in Chinese).

Li, Q., J. Wang, H.Y. Sun, and X. Shang. 2014. Flower color patterning in pansy (Viola $\times$ wittrockiana Gams.) is caused by the differential expression of three genes from the anthocyanin pathway in acyanic and cyanic flower areas. Plant Physiol. Biochem. 84:134141.

Liu, C. 2008. The preliminary studies on inheritance laws of main ornamental traits of pansy 
(Viola $\times$ wittrockiana) and selection of good crossing combination of pansy and Viola (V. cornuta). Huazhong Agricultural Univ., Wuhan, China. MS thesis. (in Chinese).

Marame, F., L. Dessalegne, C. Fininsa, and R. Sigvald. 2009. Heterosis and heritability in crosses among Asian and Ethiopian parents of hot pepper genotypes. Euphytica 168(2):235247.

Marcussen, T., L. Heier, A.K. Brysting, B. Oxelman, and K.S. Jakobsen. 2015. From gene trees to a dated allopolyploid network: Insights from the angiosperm genus Viola (Violaceae). Syst. Biol. 64(1):84-101.

Marcussen, T., T. Karlsson, P. Wind, and B. Jonsell. 2010. Violaceae, p. 12-52. In: B. Jonsell and T. Karlsson (eds.). Flora Nordica 6. The Bergius Foundation, Royal Swedish Academy of Sciences, Stockholm.

Miyajima, D. 2006. Pollination and seed production in Viola. HortScience 41:633-639.
Qiao, B., H. Huang, X. Zhang, C. Ma, and D. Li. 2004. Simple methods for measuring the leaf area of strawberry. Guoshu Xuebao 21(6):621623 (in Chinese).

Reimann-Philipp, R. 1983. Heterosis in ornamentals, p. 234-259. In: R. Frankel (ed.). Heterosis. Monographs on Theoretical and Applied Genetics, vol. 6. Springer, Berlin.

Słomka, A., J. Żabicka, L. Shuka, J. Bohdanowicz, and E. Kuta. 2018. Lack of correlation between pollen aperture number and environmental factors in pansies (Viola L. sect. Melanium Ging.): Pollen heteromorphism re-examined. Plant Biol. 20(3):555-562.

Szczudło, A. 2004. Heteromorfizm i żywotność pyłku u wybranych taksonów rodzaju Viola L. Jagiellonian Univ., Cracow, Poland. Bachelor's thesis (in Polish).

Vukics, V., A. Kery, G.K. Bonn, and A. Guttman. 2008. Major flavonoid components of heartsease (Viola tricolor L.) and their antioxidant activities. Anal. Bioanal. Chem. 390(7):19171925.

Yockteng, R., H.E. Ballard, Jr., G. Mansion, I. Dajoz, and S. Nadot. 2003. Relationships among pansies (Viola section Melanium) investigated using ITS and ISSR markers. Plant Syst. Evol. 241(3-4):153-170.

Yoshioka, Y., H. Iwata, N. Hase, S. Matsuura, R. Ohsawa, and S. Ninomiya. 2006. Genetic combining ability of petal shape in garden pansy (Viola $\times$ wittrockiana Gams) based on image analysis. Euphytica 151(3):311-319.

Zhang, Q., M. Bao, X. Lu, and H. Hu. 2010. Research advances in breeding of pansy (Viola $\times$ wittrockiana). Chinese Bul. Bot. 45(1):128 133 (in Chinese)

Zhang, X. and Y. Gu. 2009. Elementary study on breeding background of pansy and two method of pansy breeding. Chinese Agr. Sci. Bul. 25(22): 201-206 (in Chinese). 